\title{
Prevalence of Cigarette Smoking and Nicotine Dependence Among Physicians and Employees and Their Attitude Towards Smoke Free Workplace
}

\author{
${ }^{1}$ Gehad Mohamed Abo El Matty Shahbo, ${ }^{2}$ Bindu Bharathi, ${ }^{3}$ Annabel Lee Daoala \\ Ph.D, MSN, BSN, RN, RM $M^{l}, M S N, B S N, R N, R M^{2}, M S N, B S N, R N, R M^{3}$ \\ ${ }^{I}$ Assistant Professor, Community Health Nursing, Port- Said University, Egypt \\ ${ }^{2,3}$ Lecturer, Department of Community Health Nursing, Northern Border University, Saudi Arabia
}

\begin{abstract}
This study aimed to evaluate cigarette smoking and nicotine dependence among physicians and employees and their attitudes towards smoke free workplace in Port-said City. A cross-sectional survey design was used in this study during the period from June 2013 until August 2013. This study was conducted at the hospitals, private clinic and the different public health sectors in Port-said City. Sample size was 1086. Study subjects were employees and physicians. It includes 550 employees (420 males \&130 females) and 536 physicians (332 males \& 204 females). World Health Organization's smoke free workplace questionnaire was the tool used in this study. Fagerstrom test for nicotine dependence was used to assess the degree of nicotine dependence among smokers. The cut off point was taken at 6 on 10 point scale. The result of the study shows that $35.7 \%$ of the employees were smokers but only $23.13 \%$ of the physicians were having the habit of smoking. The majority of the samples were worked in shared office; $76.4 \%$ of employees, while $51 \%$ of the physicians so they were subjected to fumes of others, or they were affecting others. The percentage of the current smokers of employees, about $40.8 \%$ used to smoke their first cigarettes within the 5 minutes after waking up, while $18.5 \%$ among physicians. Around $28.6 \%$ of employees and $18.5 \%$ of physicians smoked even if they were ill. About $51 \%$ of employees and $37.1 \%$ of physicians can smoke 11 to 20 cigarettes per/day. The mean score of Fagerstrom test of smokers who want to quit was 4.9 and 2.1 standard deviation while for those who would not want to quit was 6.4 and 2.2 of standard deviation. There was a relationship between being smokers who would quit or not and their total score in nicotine dependence test, $(P<0.0001)$. Total ban of smoking in public places was chosen by the majority of participants, but nicotine dependence may play as an obstacle to achieve this objective. Smoking cessation programs should consider a dependence treatment program.
\end{abstract}

Key words: Nicotine dependence, Tobacco, attitudes, beliefs, smoking, smoke free workplaces, cigarettes smoking,

\section{Introduction}

Smoking represents a critical international issue for public health policymakers and strategists. According to the World Health Organization, tobacco is the second major cause of death and the fourth most common risk factor for diseases worldwide. If the current trends continue, by 2020 it will have cause around 10 million deaths each year, with approximately 650 million fatalities overall. There are more than 4,000 different compounds in tobacco smoke. More than 40 of the chemicals in tobacco are known to cause cancer ${ }^{1}$. Nicotine is the drug in tobacco that makes smoking a powerful addiction. Experts rank nicotine ahead of alcohol, cocaine and heroin with regard to the severity of dependence resulting from its use. Tobacco dependence is also recognized as a disease in the World Health Organization's International Classification of Diseases (ICD-10) and the American Psychiatric Association's Diagnostic and Statistical Manual (DSM-IV). In developed countries a large proportion of smokers want to stop smoking and many try to stop, but the corresponding proportions in developing countries are low. Quit rates are also low in many developing countries. Smokers who try to quit often find it difficult because of the addictive properties of nicotine ${ }^{2}$. Smoking harms the health of smokers and those around them. Smokers are at far higher risks of strokes, heart attacks and other cardiovascular diseases; cancers of lungs, mouth, larynx, bladder, pancreas, kidneys and stomach; emphysema, bronchitis, and tuberculosis. These diseases cause serious illness, disability and premature death. Tobacco causes 4 million deaths worldwide each year, and the numbers are raising fast ${ }^{3-5}$.

Tobacco smoke also harms non-smokers exposed to so-called second hand smoke or, Environmental Tobacco Smoke (ETS). In addition, to smell and irritation to eyes, ETS exposure increases the risk of lung cancer, cardio-vascular and respiratory diseases ${ }^{6}$. In USA alone, each year ETS kills an estimated 35,000 to 65,000 adult nonsmokers from lung cancer. This is a small fraction of global deaths from ETS. ETS exposure is common in workplaces. In 1996, an estimated 130 million adult non-smokers in China were exposed to 
workplace ETS. In the UK in 1999, more than 3 million non-smokers were continuously or frequently exposed to tobacco smoke at work. In France, where there are laws restricting smoking in public spaces, $40 \%$ of employees are still exposed to ETS. ETS can interact with chemicals and radiation in workplaces to produce an additive or multiplicative effect and increase significantly the risk of many occupational diseases ${ }^{2,6}$.

As per the report of Ministry of Health and Population (MOHP, 1999), over 13 million Egyptians, or one in every five, are smokers. An alarming number of students, teachers and physicians regularly smoke. Tobacco cigarette consumption increased from 26 million in 1977 to an estimated 57 billion in 1998 consistent with the tobacco epidemic experience in other countries. Although tobacco cultivation is prohibited in Egypt, yet around 39 billion cigarettes are produced every year. The percentage of smokers is increasing by $8 \%$ yearly $^{7-8}$. Physicians are highly respected in their communities. They act as role models in issues related to health, and people turn to them for advice and consultation. For this reason, they are very important in advancing any tobacco control policies. Data from this survey will help to find out whether there will be a possibility to achieve the goal of World Health Organization towards smoke-free workplace or not.

\section{I.1 Statement of the Problem}

Prevalence of cigarette smoking and Nicotine Dependence among Physicians and Employees and Their Attitude towards Smoke free workplace in Port - said City, Egypt

\section{I.2. Aim of the study}

This study aimed to evaluate cigarette smoking and nicotine dependence among physicians and employees and their attitudes towards smoke free workplace in Port-said city, Egypt.

\section{Objectives of the study:}

1. Determine the prevalence of cigarette smoking among physicians and employees.

2. Determine the prevalence of nicotine dependence among physicians and employees.

3. Identify the attitudes of physicians and employees towards smoke free workplace in Port-said city, Egypt.

4. Recognize the relationship of nicotine dependence to willingness of cigarette smoking cessation.

\section{1. Research Methodology}

Research Approach: Quantitative Research Approach

Research Design: A cross-sectional survey design was used in this study.

Setting: This study was conducted at the Hospitals, Private clinic and the different Public health sectors in Portsaid city, Egypt.

\section{II.2. Sample}

Population: Employees and Physicians

Sample Size: 1086

Sampling Techniques: Purposive Sampling

Samples: The subjects of the present study were selected by a purposive sampling technique. Sample size was 1086, out of those 550 employees ( 420 males \& 130 females) and 536 physicians ( 332 males \&204 females). They were at their workplaces at the time of data collection.

Inclusion criteria were including in this study: (a) Gender (males \&females), (b) physicians and employees of health sectors (private \& public) (c) willing to participate in the study.

Exclusion criteria includes (a) The person with consequences of smoking.

\section{II.3. Research Tools for data collection}

The necessary information was collected by using a questionnaire sheets (WHO Smoke free workplace survey). Questionnaire sheets used to assess the current smoking pattern of physicians and employees, their attitudes towards smoking in workplaces and their desire of assistance with cessation of smoking. Fagerstrom test for nicotine dependence (Heatherton TF, et al 1991) was used. This test scale was used to evaluate the strength of the nicotine dependence on graded scale. The score ranged from zero which means no nicotine dependence and 10 which means complete dependence on nicotine. The cutoff point is taken at 6 , below 6 means low degree of dependence on nicotine and above 6 means high degree of dependence and difficult to quit smoking. In this surveys, work place means any place in which employees, contractors, volunteers, or other persons perform duties of employment or work and include private offices, common areas, and any area, which they generally use during the course of their employment or work. 


\section{II.4. Preparatory phase:}

It include reviewing of literature and research results related to cigarette smoking, nicotine dependence among physicians, employees, using books, articles and magazines to evaluate the study tools for data collection.

\section{II.5. Pilot study:}

Pilot study was carried out on $10 \%$ of total sample and it was excluded from the study subject to test the feasibility, applicability and the clarity of the questionnaire and to estimate the length of time needed to fill the sheet. As a result of the pilot study, the necessary modification in the tools was done and the final form was developed.

\section{II.6. Implementation phase:}

Data collection period for this study was from June 2013 to August 2013, the researchers collect the data during the morning from 9A.M. to 11A.M, three days/week, at the hospitals, private clinic and the different public health sectors in port-said city. The physicians\& employees filled the questionnaires alone except few from employees who were illiterate and worked as coffee makers and on janitorial services the items of the questionnaire were read to them within 45-60minutes wherein the aim of the study were explained to them to obtain their cooperation for data collection.

\section{II.7. Ethical consideration}

At the initial interview, all subject were informed about the nature, purpose and benefits of the study and that their participations were voluntary. They were individually interviewed to evaluate cigarette smoking and nicotine dependence among physicians, employees and their attitudes towards smoking free workplace in port-said city. The time allotted to fill the questionnaire sheet was 45 minutes for each participant. Also, all the information was kept confidentially.

\section{II.8. Limitation of the study:}

The scope of the study was limited as it was restricted to those men and women who voluntarily agreed to participate.

\section{II.9. Validity and reliability:}

Validity: questionnaire sheet was revised by nursing experts. Alpha reliability it is equal (0.87).

\section{Analysis of data}

\section{Figures and Tables}

The data collected were coded, analyzed and tabulated to evaluate cigarette smoking and nicotine dependence among physicians, employees and their attitudes towards smoke free workplace in port-said city. Descriptive statistics as frequency and percentage were calculated using SPSS. Chi square test was used and $p$ values less than $\mathrm{P} \leq 0.05$ were considered as statistically significant.

Table I. Frequency Distribution of Subjects Based on Gender and Habits of Smoking

\begin{tabular}{|c|c|c|c|c|c|c|c|c|c|c|c|c|}
\hline \multirow[b]{3}{*}{ Gender } & \multicolumn{6}{|c|}{ Employees } & \multicolumn{6}{|c|}{ Physicians } \\
\hline & \multicolumn{2}{|c|}{$\begin{array}{c}\text { Currently } \\
\text { smoking }\end{array}$} & \multicolumn{2}{|c|}{$\begin{array}{c}\text { Ex-\&Non } \\
\text { Smoker }\end{array}$} & \multicolumn{2}{|c|}{ Total } & \multicolumn{2}{|c|}{$\begin{array}{l}\text { Current } \\
\text { smoking }\end{array}$} & \multicolumn{2}{|c|}{$\begin{array}{c}\text { Ex- \&Non } \\
\text { smoker }\end{array}$} & \multicolumn{2}{|c|}{ Total } \\
\hline & $\begin{array}{l}\text { Freq } \\
\text { uency }\end{array}$ & $\%$ & $\begin{array}{l}\text { Freq } \\
\text { uency }\end{array}$ & $\%$ & $\begin{array}{l}\text { Freq } \\
\text { uency }\end{array}$ & $\%$ & $\begin{array}{l}\text { Freq } \\
\text { uency }\end{array}$ & $\%$ & $\begin{array}{l}\text { Freq } \\
\text { uency }\end{array}$ & $\%$ & $\begin{array}{l}\text { Frequ } \\
\text { ency }\end{array}$ & $\%$ \\
\hline Males & 196 & 35.64 & 224 & 40.72 & 420 & 76.4 & 111 & 20.71 & 221 & 41.23 & 332 & 61.9 \\
\hline Females & 0 & 0 & 130 & 23.64 & 130 & 23.6 & 13 & 2.42 & 191 & 35.63 & 204 & 38.1 \\
\hline Total & 196 & 35.64 & 354 & 64.36 & 550 & 100 & 124 & 23.13 & 412 & 76.87 & 536 & 100 \\
\hline
\end{tabular}

Table I shows that the study subjects were 1086, which includes 550 employees and 536 Physicians, out of 550 employees $76.4 \%$ were males and $23.6 \%$ were females. Regarding 536 physicians, $61.9 \%$ of them were males and $38.1 \%$ of them were females. According to smoking status the samples were grouped in to two i.e. (a) Current smoker, (b) Ex or Nonsmokers. About 35.64\% of the employees were Smokers but among the physicians $23.13 \%$ of them were having the habit of smoking. 
Figure 1: Frequency distribution of current smokers among employees and physicians.

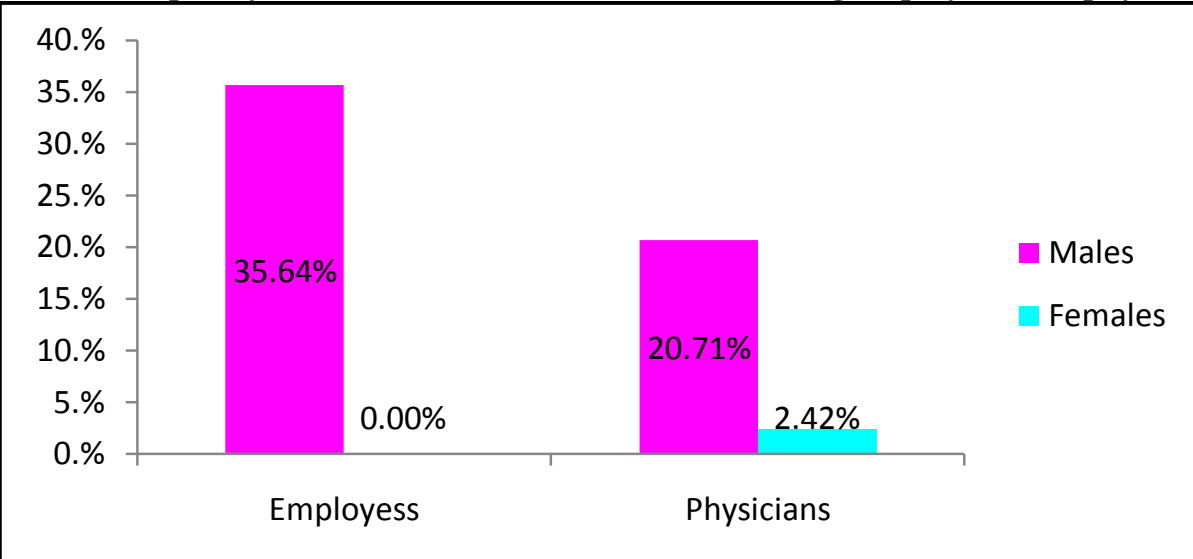

Figure 1 display that $35.64 \%$ of the employees are smokers and $20.71 \%$ of the physicians were smokers, but $2.42 \%$ of the female doctors were also smokers.

Table 2: Distribution of employees and physicians according to the status of work place.

\begin{tabular}{|c|c|c|c|c|}
\hline \multirow[b]{2}{*}{ Work Place } & \multicolumn{2}{|c|}{ Employee } & \multicolumn{2}{|c|}{ Physician } \\
\hline & Frequency & $\%$ & Frequency & $\%$ \\
\hline Single Office & 60 & 10.9 & 124 & 23.1 \\
\hline Shared Office & 420 & 76.4 & 277 & 51.7 \\
\hline Public Office & 70 & 12.7 & 83 & 15.5 \\
\hline Others & -- & -- & 52 & 9.7 \\
\hline$\chi^{2}=103.7$ & \multicolumn{4}{|c|}{ Significant at 0.05} \\
\hline \multicolumn{5}{|l|}{$\begin{array}{l}\text { Bothered because of } \\
\text { smoking in their } \\
\text { workplace }\end{array}$} \\
\hline Yes & 350 & 63.6 & 420 & 78.4 \\
\hline No & 200 & 36.4 & 116 & 21.6 \\
\hline$\chi^{2}=28.1$ & \multicolumn{4}{|c|}{ Significant at 0.05} \\
\hline \multicolumn{5}{|l|}{$\begin{array}{l}\text { Moved because of } \\
\text { smoking in their } \\
\text { workplace }\end{array}$} \\
\hline A lot & 150 & 27.3 & 99 & 18.5 \\
\hline Sometimes & 150 & 27.3 & 142 & 26.5 \\
\hline Never & 250 & 45.4 & 295 & 55.0 \\
\hline$\chi^{2}=14.2$ & \multicolumn{4}{|c|}{$\begin{array}{l}\text { Significant } \text { at } 0.05 \\
\end{array}$} \\
\hline
\end{tabular}

Table 2 illustrates that the samples where exposed to fumes of others or they were the source of fumes that affects others. About $76.4 \%$ of employees and $51.7 \%$ of physicians were have shared work place; $63.6 \%$ of employees and $78.4 \%$ of physicians were bothered by smoking in their working places and they moved from the work place because of smoking; while $45.4 \%$ of employees and $55 \%$ of physicians never moved because of smoking.

Table 3: Smoker's behaviors in work place

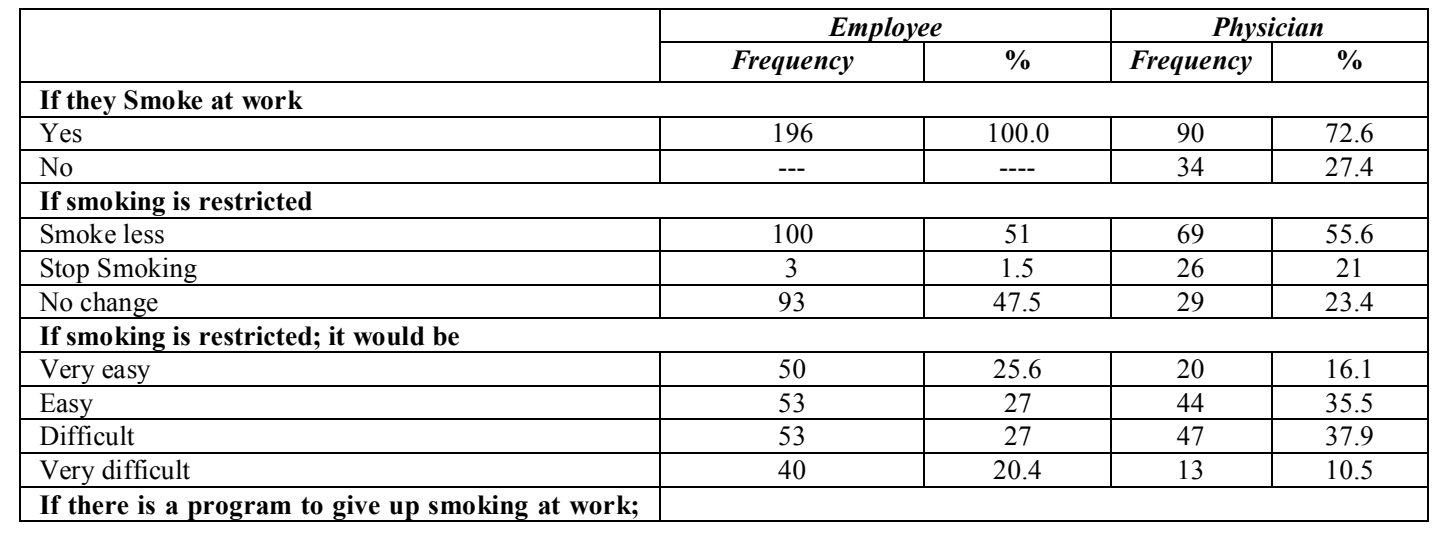




\begin{tabular}{|l|c|c|c|c|}
\hline would you join it? & \multicolumn{4}{|l|}{} \\
\hline Yes & 150 & 76.53 & 93 & 75 \\
\hline No & 46 & 23.47 & 31 & 25 \\
\hline
\end{tabular}

Table 3 shows the distribution of smoker's behavior in the work place, All most all employees are smoking at work place ( $100 \%$ ) but $72.6 \%$ of the physicians were smoked in their own work place. About half of the employees (51\%) and more than half $(55.6 \%)$ of the physicians will smokeless if restriction to smoking is present in their working place, while only $1.5 \%$ of employees and $21 \%$ of physician stop smoking in case of any restriction. On the contrary, around $20.4 \%$ of employees and $10.5 \%$ of physicians found it very difficult if restriction to smoking will take place. More than two thirds in both employees $(76.53 \%)$ and physicians $(75 \%)$ smokers would join a smoking cessation program when conducted at work.

Table 4: The attitude of physicians and employees towards smoking in workplace according to their smoking status.

\begin{tabular}{|c|c|c|c|c|c|c|c|c|c|c|c|c|}
\hline \multirow{3}{*}{ Items } & \multicolumn{6}{|c|}{ Employee } & \multicolumn{6}{|c|}{ Physician } \\
\hline & \multicolumn{2}{|c|}{ Current smoking } & \multicolumn{2}{|c|}{ Ex- \&Non smoker } & \multicolumn{2}{|c|}{ Total } & \multicolumn{2}{|c|}{ Current smoking } & \multicolumn{2}{|c|}{$\begin{array}{c}\text { Ex- \&Non } \\
\text { smoker }\end{array}$} & \multicolumn{2}{|c|}{ Total } \\
\hline & Frequency & $\%$ & Frequency & $\%$ & Frequency & $\%$ & Frequency & $\%$ & Frequency & $\%$ & Frequency & $\%$ \\
\hline $\begin{array}{l}\text { Not } \\
\text { allowed }\end{array}$ & 12 & 2.7 & 200 & 94.3 & 212 & 38.5 & 44 & 12.8 & 299 & 87.2 & 343 & 64.0 \\
\hline $\begin{array}{l}\text { Allowed } \\
\text { in rest } \\
\text { period }\end{array}$ & 100 & 50.0 & 100 & 50.0 & 200 & 36.4 & 51 & 35.4 & 93 & 64.6 & 144 & 26.9 \\
\hline $\begin{array}{l}\text { Allowed } \\
\text { if most } \\
\text { agree }\end{array}$ & 19 & 44.2 & 24 & 55.8 & 43 & 7.8 & 6 & 46.2 & 7 & 53.8 & 13 & 2.4 \\
\hline $\begin{array}{l}\text { Allowed } \\
\text { if all } \\
\text { agree }\end{array}$ & 20 & 40.0 & 30 & 60.0 & 50 & 9.1 & 18 & 66.7 & 9 & 33.3 & 27 & 5.0 \\
\hline $\begin{array}{l}\text { Allowed } \\
\text { any } \\
\text { where }\end{array}$ & 45 & 100.0 & & 100.0 & 45 & 8.2 & 5 & 55.6 & 4 & 44.4 & 9 & 1.7 \\
\hline Total & 196 & 35.6 & 354 & 64.4 & 550 & 100.0 & 124 & 23.1 & 412 & 76.9 & 536 & 100.0 \\
\hline
\end{tabular}

Table 4 shows that the attitude of employees and physicians towards smoking in workplace according to their smoking status; the sample was divided into current smokers, ex and nonsmokers; majority of the physicians, $64 \%$ chosen not to allow smoking in workplace, while $38.5 \%$ of employees. In connection with the timing or condition that smoking is allowed, most of the samples agreed to have it during rest period, among employees (36.4\%) responded yes and $26.9 \%$ among physicians.

Table 5: The attitude of physicians and employees towards restriction of smoking in some public places.

\begin{tabular}{|c|c|c|c|c|c|c|c|c|c|c|c|c|c|c|c|c|}
\hline \multirow{3}{*}{ Places } & \multicolumn{8}{|c|}{ Employee } & \multicolumn{8}{|c|}{ Physician } \\
\hline & \multicolumn{2}{|c|}{$\begin{array}{c}\text { Total } \\
\text { banning }\end{array}$} & \multicolumn{2}{|c|}{$\begin{array}{l}\text { Separate } \\
\text { area }\end{array}$} & \multicolumn{2}{|c|}{$\begin{array}{c}\text { Smoking } \\
\text { at certain } \\
\text { time }\end{array}$} & \multicolumn{2}{|c|}{$\begin{array}{c}\text { No } \\
\text { restriction }\end{array}$} & \multicolumn{2}{|c|}{$\begin{array}{c}\text { Total } \\
\text { banning }\end{array}$} & \multicolumn{2}{|c|}{$\begin{array}{l}\text { Separate } \\
\text { area }\end{array}$} & \multicolumn{2}{|c|}{$\begin{array}{l}\text { Smoking } \\
\text { at certain } \\
\text { time }\end{array}$} & \multicolumn{2}{|c|}{$\begin{array}{c}\text { No } \\
\text { restriction }\end{array}$} \\
\hline & $\begin{array}{c}\text { Freq } \\
\text { uenc } \\
y\end{array}$ & $\%$ & $\begin{array}{c}\text { Freq } \\
\text { uenc } \\
y\end{array}$ & $\%$ & $\begin{array}{c}\text { Freq } \\
\text { uenc } \\
y\end{array}$ & $\%$ & $\begin{array}{c}\text { Freq } \\
\text { uenc } \\
y\end{array}$ & $\%$ & $\begin{array}{c}\text { Freq } \\
\text { uenc } \\
y\end{array}$ & $\%$ & $\begin{array}{c}\text { Freq } \\
\text { uenc } \\
y\end{array}$ & $\%$ & $\begin{array}{l}\text { Fre } \\
q u e \\
\text { ncy }\end{array}$ & $\%$ & $\begin{array}{l}\text { Fre } \\
\text { que } \\
\text { ncy }\end{array}$ & $\%$ \\
\hline Toilet & 325 & 59.1 & 40 & 7.3 & 15 & 2.7 & 5 & 0.9 & 249 & 46.5 & 30 & 5.6 & 12 & 2.2 & 0 & 0 \\
\hline $\begin{array}{l}\text { Restaura } \\
n t\end{array}$ & 250 & 45.5 & 110 & 20.0 & 20 & 3.6 & 20 & 3.6 & 262 & 48.9 & 103 & 19.2 & 11 & 2.1 & 24 & 4.5 \\
\hline $\begin{array}{l}\text { Cafeteri } \\
a\end{array}$ & 200 & 36.36 & 150 & 27.4 & 30 & 5.5 & 35 & 6.4 & 194 & 36.2 & 133 & 24.8 & 28 & 5.2 & 45 & 8.4 \\
\hline $\begin{array}{l}\text { Sport } \\
\text { area }\end{array}$ & 350 & 63.64 & 50 & 9.1 & 10 & 1.8 & 10 & 1.8 & 343 & 64.0 & 33 & 6.2 & 13 & 2.4 & 11 & 2.1 \\
\hline Lifts & 324 & 58.9 & 20 & 3.6 & 9 & 1.6 & 7 & 1.3 & 82 & 71.3 & 9 & 1.7 & 7 & 1.3 & 2 & 0.4 \\
\hline $\begin{array}{l}\text { Corridor } \\
S\end{array}$ & 250 & 45.5 & 40 & 4.3 & 30 & 5.5 & 70 & $\begin{array}{c}12 . \\
7\end{array}$ & 247 & 46.1 & 39 & 7.3 & 27 & 5.0 & 87 & 16.2 \\
\hline
\end{tabular}


Table 5 shows the opinion of the participants about restriction of smoking in public places; as it has been observed that total banning in sports area is chosen by majority of employees (63.64\%), while among the physicians $(71.3 \%)$ in lifts. The least restricted public areas identified by the samples were the toilet, $0.9 \%$ employees and $0 \%$ from the physician responded "no restriction".

Table 6: Demonstrates tendency to quit smoking against gender.

\begin{tabular}{|l|c|c|c|c|c|c|c|c||}
\hline \multirow{2}{*}{ Items } & \multicolumn{4}{|c|}{ Employee (n= 196) } & \multicolumn{4}{c||}{ Physician (n=124) } \\
\cline { 2 - 10 } & \multicolumn{2}{|c|}{ Males } & \multicolumn{2}{c|}{ Females } & \multicolumn{2}{c|}{ Males } & \multicolumn{2}{c||}{ Females } \\
\cline { 2 - 10 } & Frequency & $\%$ & Frequency & \% & Frequency & \% & Frequency & \% \\
\hline Want to quit & 121 & 61.7 & ----- & ----- & 85 & 76.6 & 7 & 53.8 \\
\hline $\begin{array}{l}\text { Do not want to } \\
\text { quit }\end{array}$ & 75 & 38.3 & ------- & -------- & 26 & 23.4 & 6 & 46.2 \\
\hline Total & 196 & 100.0 & 0 & 0 & 111 & 100.0 & 13 & 100.0 \\
\hline
\end{tabular}

Table 6 displays that there is a higher tendency of the smokers to quit. There has been a strong willingness to quit smoking which includes $61.7 \%$ male employees (no female samples among employees who are currently smoking) and $76.6 \%$ among male physicians and $53.8 \%$ for female physicians.

Table 7. Fagerstrom Test for Nicotine Dependence.

\begin{tabular}{|c|c|c|c|c|c|}
\hline \multirow[b]{2}{*}{ Question } & \multirow[b]{2}{*}{ Answer } & \multicolumn{2}{|c|}{ Employee } & \multicolumn{2}{|c|}{ Physician } \\
\hline & & Frequency & $\%$ & Frequency & $\%$ \\
\hline \multirow{4}{*}{$\begin{array}{l}\text { How soon after you wake up } \\
\text { do smoke first cigarette }\end{array}$} & Within 5 minutes & 80 & 40.8 & 23 & 18.5 \\
\hline & $6-30$ minutes & 40 & 20.4 & 41 & 33.1 \\
\hline & $31-60$ minutes & 54 & 27.6 & 28 & 22.6 \\
\hline & $61+$ minutes & 22 & 11.2 & 32 & 25.8 \\
\hline \multirow{2}{*}{$\begin{array}{l}\text { Do you find it difficult to } \\
\text { refrain from smoking in } \\
\text { places where it is forbidden? }\end{array}$} & Yes & 110 & 56.1 & 10 & 8.4 \\
\hline & No & 96 & 43.9 & 114 & 91.9 \\
\hline \multirow{2}{*}{$\begin{array}{l}\text { Which cigarette would you } \\
\text { hate most to give up? }\end{array}$} & First in the Morning & 119 & 60.7 & 78 & 62.9 \\
\hline & All others & 77 & 39.3 & 46 & 37.1 \\
\hline \multirow{4}{*}{$\begin{array}{l}\text { How many cigarettes per day } \\
\text { do you smoke? }\end{array}$} & 10 or less & 30 & 15.3 & 46 & 37.1 \\
\hline & $11-20$ & 100 & 51 & 46 & 37.1 \\
\hline & $21-30$ & 43 & 21.9 & 18 & 14.6 \\
\hline & 31 or more & 23 & 11.7 & 14 & 11.2 \\
\hline \multirow{2}{*}{$\begin{array}{l}\text { Do you smoke more } \\
\text { frequently during the first } \\
\text { hours? After waking than } \\
\text { during the rest of the day }\end{array}$} & Yes & 110 & 56.1 & 50 & 40.3 \\
\hline & No & 86 & 43.9 & 76 & 59.7 \\
\hline \multirow{2}{*}{$\begin{array}{l}\text { Do you smoke if you are ill } \\
\text { that you are in bed most of } \\
\text { the day? }\end{array}$} & Yes & 56 & 28.6 & 23 & 18.5 \\
\hline & No & 140 & 71.4 & 101 & 81.5 \\
\hline
\end{tabular}

Table 7 shows the responses of the samples on the Fagerstrom test for Nicotine Dependence. The result showed that $40.8 \%$ of employees and $18.5 \%$ of physicians smoked their first cigarette within the 5 minutes after waking up. Around $51 \%$ of employees and $37.1 \%$ of physician can consume between 11 to 20 cigarettes per day. About 28.6\% employees and 18.5\% physicians were smoking still even if the samples were ill.

Table8: Nicotine dependence level, using Fagerstrom test.

\begin{tabular}{|c|c|c|c|c|c|c|c|c|}
\hline \multirow{3}{*}{$\begin{array}{c}\text { Nicotine } \\
\text { dependence level } \\
\end{array}$} & \multicolumn{4}{|c|}{ Employee $(n=196)$} & \multicolumn{4}{|c|}{ Physician $(n=124)$} \\
\hline & \multicolumn{2}{|c|}{ Want to quit } & \multicolumn{2}{|c|}{ Do not want to quit } & \multicolumn{2}{|c|}{ Want to quit } & \multicolumn{2}{|c|}{ Do not want to quit } \\
\hline & Frequency & $\%$ & Frequency & $\%$ & Frequency & $\%$ & Frequency & $\%$ \\
\hline Less than 6 & 86 & 71.1 & 22 & 29.3 & 60 & 65.2 & 1 & 3.1 \\
\hline 6 and more & 35 & 28.9 & 53 & 70.7 & 32 & 34.8 & 31 & 96.9 \\
\hline Total & 121 & 100.0 & 75 & 100.0 & 92 & 100.0 & 32 & 100.0 \\
\hline $\mathrm{X}^{2}$ & \multicolumn{4}{|c|}{70.3} & \multicolumn{3}{|c|}{ significant } & 0.05 \\
\hline
\end{tabular}


Table 8 shows that result of Fagerstrom test for Nicotine dependence. Among the samples $71.1 \%$ employees and $65.2 \%$ most of them scored less than 6 out of 10 which means low level of nicotine dependence and having the highest possibility of quitting from smoking. On the other hand the willingness to quit is very low among the samples classified as high nicotine dependence $28.9 \%$ for employees and $34.8 \%$ for physicians.

\section{Discussion}

Demand of tobacco is continuously on the rise despite rigorous efforts in prohibiting its use and controlling its production. According to the report of WHO (2010), currents smokers all over the world is about 1 billion ${ }^{1}$. This study was able to find out the prevalence of smoking which was $29.47 \%$ of the total population of 1,086 employees and physicians of the private and public health sectors in Port Side City, Egypt. The record of WHO Report on the Global Tobacco Epidemic, 2013, identified that there is a total of 3.7\% among the youth who are currently cigarette users, while $24.4 \%$ were currently tobacco smokers among adults ${ }^{2}$. Reports also relate smoking among male population but nowadays female population is also having the habit of smoking. According to Hitchman S. \& Fong, G (2011), as to the frequency of smoking, male smokes approximately five times as much as female but its proportion is different from each country. The ratio of male to female in high income countries like United States, Canada and etc. women smokes almost the same rate with men. On the other hand, the middle to low income countries records shows that there is a lower smoking prevalence rate to women ${ }^{11}$, which is also true with this study that among the samples identified there is a higher ratio for male smokers which is $35.64 \%$ from male employees while $0 \%$ female employees and $20.71 \%$ smokers among the male physicians while $2.42 \%$ from female physicians. With this result it has been observed that there is a higher prevalence of smoking among employees compared to physicians, but female smokers were noted among physicians $(2.42 \%)$. According to Amos, O'Keefe, \&Nerin, the pattern of smoking among females is ascending which has been associated with social factors, economic resources and a symbol of freedom which the tobacco industry's marketing of cigarettes was emphasizing ${ }^{12-14}$.

The public health policy makers were exhausting their efforts to promote smoke free workplaces. Globally mortality rate related to tobacco was projected approximately $12 \%$ of all deaths among adults aged 30 years and over ${ }^{15}$. In United States smoking kills one in every five deaths each year, thereby classified as the leading preventable cause of death ${ }^{16}$. There was a great impact noted of smoke free workplaces on motivating the smokers to totally stop or lessen their chances of smoking (Fichtenberg, C., 2002), which projects 3.8\% reduction on the prevalence of smoking and the number was also reduced on cigars smoked per day i.e. about $3.1 \%$. In line with the results of our study, majority of the samples shared offices, $76.4 \%$ among employees and $51.7 \%$ among physicians, which indicates that if somebody smokes there is a large chance of being exposed to their fumes causing passive smokers to increase. Most of the samples were also bothered if there will be somebody smoking in their workplace with a $63.6 \%$ among employees and $78.4 \%$ among physician. Although most of them will not transfer from their workplaces just because of smoking taking into consideration that they value their job rather than their exposure to smoke. Among the samples, $100 \%$ of the employees admitted that they were smoking at work, while $72.6 \%$ of the physicians were smokers, with this result high prevalence of smoking at work has been observed. The relationship of restriction as to the frequency of smoking was noted wherein among the employees $51 \%$ will lessen their frequency of smoking while $55.6 \%$ among physicians. Majority from the 1,086 samples would not allow smoking in their workplaces $38.5 \%$ of the employees and $64 \%$ of the physicians. In this result it reflects that if restriction in smoking to workplaces will be implemented there will be a great decline as to the consumption of cigarettes per day among smokers and protects the nonsmokers from passive smoking.

The WHO, explained about the tobacco - free public places which means that all indoor workplaces and indoor public places should be $100 \%$ smoke - free, thereby designating areas for smokers will break this standard and it is against the WHO Framework Convention on Tobacco Control guidelines. Furthermore, designating smoking areas is totally prohibited indoors ${ }^{17}$. From the results of this study, majority from the respondents agreed total banning of smoking in any sports areas, $63.64 \%$ of employees and $64 \%$ of physicians. Although there was a high prevalence of no restriction should be implanted along the corridors, $12.7 \%$ among employees and $16.2 \%$ among physicians. This result described the willingness of the respondents to observe smoke free workplaces but on the other hand open spaces such as corridors was determined to be a good venue for smoking.

The second leading cause of death worldwide was due to nicotine addiction ${ }^{18}$. Dependence on nicotine is characterized by both the persistence of a drug-taking behavior and the emergence of withdrawal symptoms upon the abrupt cessation of nicotine administration ${ }^{19-20}$. The result of Fagerstrom test to assess the level of 
nicotine dependence among the sample who are currently smoking, it shows that there is greater percentage of those who scored less than 6 (low level of nicotine dependence) with a total of $52.8 \%$ and $47.2 \%$ scored a scale of $6 \&$ more (high level of nicotine dependence). Nicotine is the major chemical component that is responsible for addiction in tobacco products ${ }^{30-33}$. Addiction depends on the amount of nicotine delivered, its way of delivery, rate of absorption whether its desired dose of concentration has been attained ${ }^{34-35}$.

The findings of the study of Ashton \&Streem, 2012, were that fully $70 \%$ of smokers report wanting to quit, and $46 \%$ attempt to quit each year. Only $5 \%$ to $7 \%$ of them were abstinent from smoking for an entire year after quitting. Several factors appear to affect rates of abstinence in different groups. Women have less success with quitting smoking and higher rates of relapse. Patients with higher levels of nicotine dependence (as evidenced by higher FTND scores) and those with a history of depression also have lower abstinence rates. African Americans and Chinese Americans have lower smoking cessation numbers than European Americans ${ }^{36}$. The present study shows that among the employees with low level of dependence express willingness to quit smoking with $71.1 \%$ and $65.2 \%$ among the physicians. On the other hand those sample who have been categorized to have a high level of dependence to nicotine reported of unwillingness to smoking cessation which includes $70.7 \%$ among employees and $96.9 \%$ among physicians. There is an indirect proportional relationship between motivations to quit as to the level of nicotine dependence. This explains that the higher the level of nicotine dependence the lesser the person is motivated to stop smoking, and vise verse. The result of the study shows that the relationship between the levels of nicotine dependence to smoking cessation is significant.

\section{Recommendation}

Every person has the right to a clean, healthy and smoke free environment.

1. The local government must apply restrictions to smoking in places where large numbers of persons are likely to congregate within close proximity to one another.

2. A place of lodging, bar or restaurant may designate guest rooms where smoking is allowed if those room are physically detached or if these are separately ventilated, employers shall not require nonsmoking employees to work in smoking area.

3. Protect people from involuntary exposure to tobacco smoke by establishing smoke-free public places. Tobacco dependence treatment program should be offered as a part of Smoking cessation programs.

4. Ensure adequate institution support for tobacco control capacity building, applied research, routine surveillance and program.

5. It is Necessary to apply current laws which prohibit advertisement on TV, Radio, and bans smoking on public transportation, in health care facilities, cinemas, theaters and public offices.

6. The media can assist by disseminating the message of quitting smoking to the whole population in Egypt.

7. The researchers recommend that the factors identified in this study should be taken into consideration in antismoking programmers to make them more effective and better able to influence the attitude and behaviors of smokers.

8. The community health nurse and the psychiatric nurse must be shared with oriented educational programmers in treating nicotine addiction, the creation and support of hospital-based smoking cessation centers and the continuous monitoring of compliance to existing legislations should be central to efforts that reinforce the viability of a smoke-free health care system. Further research into the factors that modify both personnel smoking habits and the health professionals' beliefs on tobacco related issues is warranted.

9. The community health nurse and the psychiatric nurse can support local communities by identifying tobacco - related problems, advocating for and assisting in planning and implementation of strategies to correct the problems, and facilitating social and structural change that supports long -term success. A community must accept ownership and feel empowered to intervene.

\section{Conclusion}

Tobacco use is becoming epidemic to any part of the world. Its effects are becoming more obvious especially on its negative impact to health. Intensive measures have been made by the authorities and every $31^{\text {st }}$ of May the World No Tobacco campaign has been celebrated with the advocacy of encouraging all countries to raise the tax for tobacco, but this seems to be somewhat not enough to motivate persons who already developed addiction to nicotine. Health care professionals and employees to health care sectors are not being excluded from this epidemic. In connection there for we must look into a more detailed and individual approach to scrutinize the reasons for nicotine dependence and the best possible approach to decrease chances of initiating and continued use of tobacco. While health professionals play a major role in tobacco control, tobacco 
consumption in this group is often high. The role and image of the health professionals are essential in promoting tobacco-free lifestyles and cultures. So we must assess the degree of nicotine dependence to design the suitable program for smokers who want to quit.

\section{Acknowledgment}

The authors are grateful to Almighty God for accomplishment of this research work. The authors are also wish to thank all the Physicians and employees for their participation of the study.

\section{References}

[1]. World Health Organization (2010). Global status report on noncommunicable diseases. Retrieved from http://www.who.int/chp/ncd global_status report/en/

[2]. World Health Organization (2013). Report on the Global Tobacco Epidemic. Retrieved from http://www.who.int/tobacco/global report/2013/en/

[3]. de Hollander A, Hoeymans N, Melse J, van Oers J, Polder Je:Zorgvoorgezondheid - VolksgezondheidToekomstVerkenning 2006. RIVM Rapport 270061003. 2006.

[4]. Peto,R.( 1994): Smoking and Dealth. The past 40 years and the next 40. BMJ. 6959 (309): 937-939

[5]. Taha A, Ball K.(1995): Tobacco and the third world; the growing threat. East Afr.Med.J; 62(10)735-41

[6]. Hammond SK, Sorensen G, Youngstrom R, Ockene JK.(1995): Occupational exposure to environmental tobacco smoke. JAMA.;274:956-960

[7]. IbnSina journal,( 2000) : The National Conference for Tobacco control. Ministry of Health and Population, National TB Control programme. No4.

[8]. Hurley SF, Matthews JP: The Quit Benefits Model: a Markov model for assessing the health benefits and health care cost savings of quitting smoking. Cost EffResourAlloc 2007, 5:2.

[9]. World Health Organization (WHO); 1997: Tobacco or Health: A global status report. 239-241

[10]. Healtherton TF, Kozlowski LT, Frecker RC, Fagerstrom KO. (1991): The Fagerstrom Test for Nicotine Dependence: A revision of the Fgerstrom Tolerance Questionnaire. British Journal of Addictions; 86:1119-27

[11]. Hitchman, S. \& Fong, G. (2011). Gender empowerment and female - to - male smoking prevalence ratios. Retrieved from http://www.who.int/bulletin/volumes/89/3/10-079905/en/

[12]. Amos A, Haglund M. From social taboo to "torch of freedom": the marketing of cigarettes to women. Tob Control 2000; 9: 3-8 doi:10.1136/tc.9.1.3 pmid: 10691743 .

[13]. O'Keefe AM, Pollay RW. Deadly targeting of women in promoting cigarettes. J Am Med WomensAssoc 1996; 51: 67-9 pmid: 8868553 .

[14]. Nerín I. [Women and smoking: fatal attraction]. Arch Bronconeumol2005; 41: 360-2 doi: 10.1016/S1579-2129(06)602413 pmid: 16029727 .

[15]. World Health Organization (2012): Mortality attributable to tobacco. Retrieved from http://www.who.int/tobacco/publications/surveillance/rep mortality attributable/en/

[16]. Surgeon General's Report (2014): The Health Consequences of Smoking — 50 Years of Progress, Chapter 12, Table 12.4

[17]. Fichtenberg, C. \&Glantz, S.; 2002, July 27. Effect of smoke-free workplaces on smoking behaviour: systematic review. Retrieved from http://dx.doi.org/10.1136/bmj.325.7357.188

[18]. Lande, G. \&Dunayevich, E. (2014). Nicotine addiction. Retrieved from http://emedicine.medscape.com/article/287555-overview

[19]. Wikler A. Dynamics of drug dependence. Implications of a conditioning theory for research and treatment. Archives of General Psychiatry 1973;28(5):611-6.

[20]. Levine DG. "Needle freaks": compulsive self-injection by drug users. American Journal of Psychiatry 1974; 131(3):297-300.

[21]. Stewart J, de Wit H, Eikelboom R. Role of unconditioned and conditioned drug effects in the self-administration of opiates and stimulants. Psychological Review 1984;91(2):251-68.

[22]. Ludwig AM. Pavlov's "bells" and alcohol craving. Addictive Behaviors 1986;11(2):87-91.

[23]. O'Brien CP, Childress AR, McLellan T, Ehrman R. Integrating systemic cue exposure with standard treatment in recovering drug dependent patients. Addictive Behaviors 1990;15(4):355-65.

[24]. Hughes JR, Hatsukami DK. The nicotine withdrawal syndrome: a brief review and update. International Journal of Smoking Cessation 1992;1(2):21-6.

[25]. Koob GF, Markou A, Weiss F, Schulteis G. Opponent process and drug dependence: neurobiological mechanisms. Seminars in Neuroscience 1993;5(5):351-8.

[26]. Markou A, Kosten TR, Koob GF. Neurobiological similarities in depression and drug dependence: a self-medication hypothesis. Neuropsychopharmacology1998; 18(3):135-74.

[27]. American Psychiatric Association. Diagnostic and Statistical Manual of Mental Disorders. 4th ed. Washington: American Psychiatric Association, 1994.

[28]. Kenny PJ, Markou A. Neurobiology of the nicotine withdrawal syndrome. Pharmacology, Biochemistry and Behavior 2001; 70(4):531-49.

[29]. U.S. Department of Health and Human Services. How Tobacco Smoke Causes Disease-The Biology and Behavioral Basis for Smoking-Attributable Disease: A Report of the Surgeon General. Atlanta (GA): U.S. Department of Health and Human Services, Centers for Disease Control and Prevention, National Center for Chronic Disease Prevention and Health Promotion, Office on Smoking and Health, 2010

[30]. U.S. Department of Health and Human Services. The Health Consequences of Smoking: Nicotine Addiction. A Report of the Surgeon General. Atlanta (GA): U.S. Department of Health and Human Services, Public Health Service, Centers for Disease Control, National Center for Chronic Disease Prevention and Health Promotion, Office on Smoking and Health, 1988. DHHS Publication No. (CDC) 88-8406.

[31]. Stolerman IP, Jarvis MJ. The scientific case that nicotine is addictive. Psychopharmacology 1995;117(1):2-10; discussion 4-20. 
[32]. Royal College of Physicians of London. Nicotine Addiction in Britain: A Report of the Tobacco Advisory Group of the Royal College of Physicians. London: Royal College of Physicians of London, 2000.

[33]. Balfour DJ. The neurobiology of tobacco dependence: a preclinical perspective on the role of the dopamine projections to the nucleus accumbens [corrected]. Nicotine \& Tobacco Research 2004;6(6):899-912.

[34]. Henningfield JE, Keenan RM. Nicotine delivery kinetics and abuse liability. Journal of Consulting and Clinical Psychology 1993;61(5):743-50.

[35]. de Wit H, Zacny J. Abuse potential of nicotine replacement therapies. CNS Drugs 1995;4(6):456-68

[36]. Ashton, K., \&Streem, D., (2012, August). Smoking cessation. Retrieved http://www.clevelandclinicmeded.com/medicalpubs/diseasemanagement/psychiatry-psychology/smoking-cessation/\#top

from 